\title{
THE SEPARATION BETWEEN STATE AND RELIGION IN ISLAM ?
}

\author{
By: Kamaruzzaman Bustamam Ahmad
}

\section{Abstrak}

Paper ini bermaksud mempertanyakan kembali gagasan pemisahan antara negara dan agama dalam Islam. Berangkat dari pemikiran Ira M. Lapidus dalam sebuah tulisannya, penulis melakukan elaborasi yang lebih mendalam tentang relasi agama dan negara dengan menelusuri sejarah lahirnya negara, baik di Barat maupun Islam. Sebuah kesimpulan yang kemudian dimunculkan, bahwa tidak ada sumber data yang mendukung bahwa dalam Islam, agama dan negara mesti dipisahkan. Gagasan sekularisasi hanya ada di Barat sebagaimana yang diajarkan al Kitab. Adapun dalam Islam, ada banyak data, baik normatif maupun historis yang menunjukkan hubungan yang sangat dekat antara agama dan negara.

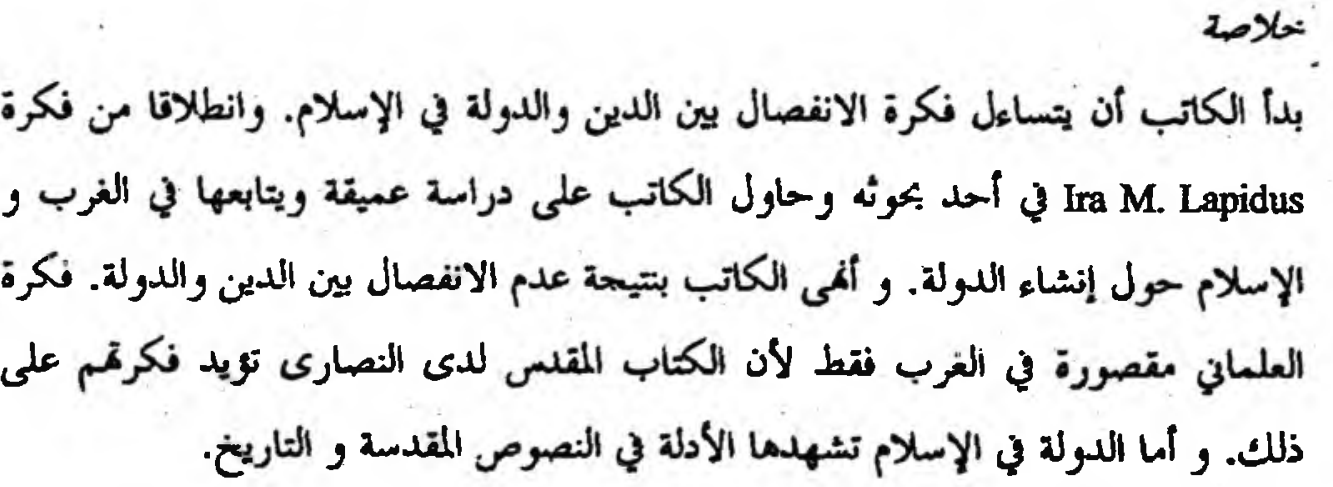

Keywords: State, Religion, Islam

\footnotetext{
- The Student of Gradute Program of Islamic Politic in Southeast Asia of University of Malaya Kuala Lumpur, Malaysia.
} 


\section{A. Introduction}

Whis article based on Ira M Lapidus essay concerning separation of state and religion in Islam. ${ }^{1}$ In her complete of article, Lapidus arose many questions relating to separation of state and religion in Islam. The questions are how were religious communities organized? What parts did the 'ulamá' play within them? What relations did they have with common people? How deeply did religious and sectarian identifications penetrate the Muslim masses? What social and religious functions did the 'ulamá' and organized communities play in the ongoing life of Muslim communities? How were relations between Muslim communities and Muslim states? How were these relations formed under different regimes, in different localities; how did the change over time? To what extent did the 'ulamá' influence the development of the state? To what extent did the state control the 'ulumâ' and sectarian communities? May we not speak of distinction between church and state in Islam? How may we described and explain the Islamic situation if it represent neither the unity posited by Islamists for the early Caliphate nor the thorough institutional differentiation evident in the Christian Europe? In addition, in finishing of her investigation, Lapidus also said:

Though the modalities of 'state' and 'religion' in the Islamic world are quite different from those of 'state' and 'church' in the west, Islamic society, in fact, if not in its own theory, is one of those societies in which religious and political institutions are separate. The implications of this fact for the operation of regimes, for the structures of communities, for moral situation of the individual Muslim believer runs through the whole fabric of Islam. ${ }^{2}$

From atop we have seen that three topics are always connected by religion and state in Islam: Islamic concepts or Islamic theory about state, Islamic community in state or the experience of Muslim actualized the state, and the role of Islamic leaders in constructed a state, 'ulamâ and umara.' First topics, we could comprehended numerous books and articles, both Arabic and English, that discussing about Islamic theory of state. Beside this, the topic was on epistemological questions: what, why, how the Islamic state. ${ }^{4}$ Moreover, the two topics later were sociological and historical approach. On other word, we

\footnotetext{
'See Ira M. Lapidus, 1975, “The Separation of State and Religion in The Deveiopment of Early Islamic Society," International Journal Middle East Studies, 6; p. 363 85.

"Ibid., p. 385.

"On this, see e.g. Muhammad Qasim Zaman, 1997, "The Caliph, The 'Ulamâ", and the Law: Defining the Role and Function of the Caliph in The Early 'Abbasid Period," Islamic Law and Society, Vol.4, No. I, 1-36.

"See al-Mawardî, al-Ahkâm al-Sultâniyyah (the Principles of Government). Beirut: Dâr al-Fikr, n.d; Abî Ya'lá, Al-Ahkâm al-Sultâniyvah (the Principles of Government), Beirut: Dâ $r$ al-Fikr, 1994. For analyze both the books, see Donald P. Little, "A New Look At Al-Ahkãm alSultâriyya," The Muslim World, Vol. LXIV, Na.1 (1974), 1-15. Sec also Ibn Taymiyya, 1998, al-Khilajfah 'u'a al-Mulk, Yordan: Maktabah al-Manâr; Mustafâ Hilmi, 1998, Nidâm al-Kilafâh Bain Ahl al-Sunnah wa al-Syîăh: Muktasâr Nidâm al-Kilaföh fi al-Fỉhr al-Islâmiyý, Iskandariyyah: Dâr al-Da'wah; Mahmud A.
} 
examine the history of Muslim that related with the politic, namely Islamic government, as long as, politic commonly connects with state, government, and how to administer the people in certain of territory.

Meanwhile, we discuss of religion and politic (state), however, it needs consider that between them were different in one side and similar in another : one.' Actually, religion was a revelation from God for guidance of man in biosphere and hereafter; and, it has values and norms that what people must obey and disobey. Nevertheless, man made the politic, that was a consensus between them, and there was an interesting public that government handled by some peoples whom elected by themselves with many methods. ${ }^{6}$ On other words, the politic and religion need each other. The religion requirement the politic for defend of its extension in the world. More or less, religions grow up or lastly influenced by politic and occasionally, politic may not escape from the religion. ${ }^{7}$

In this essay, we will focus on the question of disjoining religion and state in Islam. I argue there was in Islam any problem that its believers were not ready to apply what did Allah said in the Holy Book and the Prophet had practice it in his era of life. Besides this, there was also West intervencion in searching of state in Islam, both imperialism and intellectualism forms.

Accordingly, the article, after introduction, will begins in giving a framework conceptual of state in Islam. In this section, it will be compare with concept of state in the West, and give each approach in study of state. After that, the writer explains why and how state can build in Moslem country. The results of the investigation will locus on concluding remarks.

\section{B. The Emergence of State in the West}

As already mentioned above that an epistemology question about state, of course, we must make an approach to study of this discipline. ${ }^{8}$ Miriam Budiarjo, in her book covered four meaning of state according western scholar. First,

Faksh, 19983, "Theories of State in Islamic Political Thought," Journal of South Asian and Middle Eastern Studies, Vol. VI, No.3, Spring, 1983, 62-79; Majid Khadduri, "The Juridical Theory of the Islamic State, "Muslim World, Vol.41, No.3 (1951), 182-5; Sri Mulyati, "The Theory of State of Al-Mâwardî," in Sri Mulyati (et al), 1997, Islam \& Development: A Politico-Religious Response, Yogyakarta: Lembaga Penterjemah \& Penulis Muslim Indonesia and Permika Montreal, p. 3-43.

${ }^{5}$ For Instance, see Nurcholish Madjid, 1998, "Islam dan Politik: Suatu Tinjauan atas Prinsip-Prinsip Hukum dan Keadilan [Islam and Politic: A General Outlook from The Principles of Law and Justice]," Pàramadina, Vol.I, No.1, p. 49.

"See "Theories of System and State," in Ronald Chilcote, 1981, Theories of Comparative. Politics: the Search for Paradigm, Westview Press: Boulder, p. 139-201.

'See generally Donald Eugene Smith, 1970, Religion and Political Development. Little Brown: Boston, esp. chapter $V$ and VI.

${ }^{8}$ Epistemology (the logos or study of epistêmê) has become search for methods and foundations which enable us to be assured of the truth of out beliefs... Epistemology is the search for foundation. See Donald Polkinghome, 1983, Methodology for the Human Sciences: System of Inquiiry, State University of New 
Koger H. Soltau: "The state is an agencies or authority managing or controlling theses (common) affairs on behalf of and in the name of the community." Second, Harold J. Laski: "The state is a society which is integrated by possessing a coercive authority legally supreme over any individual or group which is part of the society. Third, Max Weber: "The state is a human society that (successfully) claims the monopoly of the legitimate use of physical force within a given territory. Finally, Robert M. Maclver: "The state is an association which, action through law as promulgated by a government endowed to this end with coercive power, inaintains within a community territorially demarcated the external conditions of order." $"$

Furthermore, the state, then in modern society's means of organizing its members. It is a construct that developed over time to satisfy the changing organizational needs of an ever-growing society. ${ }^{10}$ On other word, state in modern era operated by staff who elected by people to be the ruler. All members of this were distributed by a simple hierarchy, which is a ranking of individuals or groups based in dominance, influence, or status. "

In the West, there have many approaches to the state. In this context, Syed Serajul Islam has briefly discussed the Western approaches to the state. According to him, they are known as the pluralists or liberal democrats and the Marxist. First, the pluralist approach that believed in any political system there are numerous social, economic and political groups, with each providing inputs into the formulation of decisions of the state. ${ }^{12}$ This view parallels with the Ronald Chilcote, that "the state is a political marketplace through which filter the demands and interest of competing groups and individual." said, two views prevail; on the one hand, neutral state agencies mediate conflict that emanates from party and group competition. On the other, agencies of the state function as the bases of political power; competition among the agencies for funding determines their relationship to parties and interest groups. ${ }^{14}$

Second, the Marxist insist that the state as an institution in an instrument of

\footnotetext{
York Press: Albany, p. 10; and also D.W. Hamlyn,1971, "Epistemology," in The Encyclopedia of Philosiphy, ed. Paul Erwasds, Collier Macmillan Publisher: London: III: 5-38; Marx W. Wartofsky, 1971, "Epistemology," in The Encyclopedia of Education, ed. Lee C. Daighton, The Macmilian Company \& The Free Press: USA, III: 416-26. For framework in Political Science, see e.g. Stephen Van Evera, 1977, Guide to Methods for Students of Political Science, Comell University Press: Ithaca and London.

${ }^{9}$ Those definitions rented from original books each scholar by Miriam Budiarjo quoted, but in this article take in Miriam Budiarjo, 1999, Dasar-Dasar Ilmu Politik: the Principles of Political Science. (Jakarta: Gramedia Pustaka Utama, p. 39-40. See also Ahmad Sukardja, 1995, Piagam Madinah dan Undang-Undang Dasar 1945, UI Press: Jakarta, p. 87-8.

${ }^{10} \mathrm{John}$ A. Jacobsohn, 1998, An Introduction to Political Science, Albany: West Wasdsworth, p. 22.

"Ibid., p. 17.

"2 Syed Serajul Islam, 1997, "The Western and Islamic Approaches to the State: A Comparative Analys:," Muslim Education Quarterly, Vol.14, No.4, p. 43.

${ }^{13}$ Konald Chilcote, Theories of Comparative Politics: the Search For Paradigm, 194

"Ibid.
} 
dominant class for exploiting the subordinate classes. ${ }^{\text {is }}$ State for this groups was maintaining and expanding the capitalist system and serving the interest of the ruling are explained in terms of the instrumental use of pressure economic and political by ruling class and directly by its representatives occupying positions in the state apparatus. ${ }^{\text {ib }}$ This approach could be inspired to the nationalist movements. As Donald Eugene Smith pointed that by World War II the leadership of most nationalist movements was held by relatively politicians, many of the strongly influenced by Marxism. ${ }^{17}$

Notwithstanding, according to Serajul Islam, the Marxist approach also has certain weakness. In the first place, the Marxist ignore the extent of social and cultural diversity within classes, despite the fact that this class heterogeneity may have decisive implications for the potential for class consciousness, solidarity, and conflict. Secondly, the Marxist assume that, with the abolition of the fundamental distortion resulting from class rule (i.e., class domination), the problem of stable representation of diverse group interests, resulting from the division of labour, will be easily solved. Thirdly, the position of the instrumentalist appears in good measure to be similar to that pluralist. Finally, in relation to structuralists, it has been alieged that they aiso fail to provide any explanation of the social mechanisms that regulate the functional relationships between the state and the dominant class. ${ }^{1}$

From above, we see that in the Western did not include the religion in there. That why, they apply the ideas of secularism. Historically, in the beginning of early $20^{\text {th }}$ Century this ideology influenced to almost of the nationalist movement. This phenomenon became against with Islam that has the ideas of state; contrary with the Christian that has not the teaching of state. ${ }^{19}$ Additionally, there are many meanings of secularism. ${ }^{20}$ For instance the

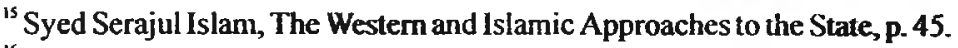

${ }^{16}$ Ibid., p. 45-6.

"Donald Eugene Smith, Religion and Political Development, p. 146. See also Samuel P. Huntington, 1998, The Clash of Civilizations and the Remaking of World Order, Touchstone Books: London, p. 52-3. For analysis of Huntington's idea see generally, Fouad Ajami, "Responses to Samuel P. Huntington"s "The Clash of Civilizations? The Summoning; 'But They Said, We Will Not Hearken' JEREMIAH 6:17; Kishore Mahbubani, "Responses to Samuel P. Huntington's "The Clash of Civilizations? The Dangers of Decadence; What the Rest Can Teach the West; Robert L. Bartley, "Resposes to Samuel P. Huntiington's "The Clash of Civilizations? " The Case for Optimism; The West Should Believe in Itself, Liu Binyan, "Responses to Samuel P. Huntington's "The Clash of Civilizations? " Civilization Grafting, No Culture is an Island; Jeane J. Kirkpatrick, "Responses to Samuel P. Huntington's "The Clash of Civilizations? " The Modemizing Imperative; Tradition and Change,"; Albert L. Weeks, “Responses to Samuel P. Huntington's "The Clash of Civilizations?" The Modernizing Imperative; Tradition and Change; Do Civilizations Hold?," http://www.coloradocollege.edu/Dept/PS/Finley/PS425/reading/Huntington2.htmL

${ }^{18}$ Syed Serajul Islam, "The Western and Islamic Approaches to the State," 45; Deliar Noer, 1999, Pemikiran Politik di Negeri Barat, Mizan: Bandung, p. 206.

19 Kamaruzzaman, 2001, Relasi Islam dan Negara: Perspektif Modernis \& Fundamentalism, Magelang: IndonesiaTera, p. 38; idem, "Reorientasi Pemikiran Kenegaraan dalan Islam," Profetïła,
} 
meaning was given by Donald Eugene Smith, when he said thet the secularization is characterized by (1) the separation of the polity from religious ideologies and ecclesiastical structures, (2) the expansion of the polity to perform regulatory functions in the socioeconomic sphere which were formerly Derformed by religious structures, and (3) the transvaluation of the political cultures to emphasize nontranscendent temporal goals and rational, pragmatic means. ${ }^{21}$ However, Nurhcolish Madjid was making the separation between secularization and secularism. He wrote that by "secularization" is not meant the applications of secularism, because "secularism" is the name of an ideology, a new closed worldview which functions very much like a new religion. What are meant here, according Madjid, are all forms of "liberating development." ${ }^{22}$ Indeed, said Madjid, by "secularization" one does mean the application of secularism and the transformation of Muslim into secularist. What is intended is the "temporalizing" of values, which are in fact worldly, and freeing of the umma from the tendency to spiritualize them. ${ }^{23}$

It is safe to say the state in the West does not support by religion, since the 'state did not based by the Holy Book, but rather as result of human intellectualization. Therefore; in the West was a region, not religion; so we could not compare with Islam as religion. As Mohammed 'A bed al-Jabri stated that:

How do we define the term 'Islam' in the expression 'Europe and Isl $\mathrm{min}$ ' which pairs two radically distinct realities, one geographic (Europe) and the other religious (Islam)? Even assuming the 'Islam' refers to the countries professing that religion, do they constitute a coherent whole. What is it trat makes Iran, or Pakistan or even Egypt, the presumed ally of Sudar Indonesia or Morocco against Europe? Are relations between these countries not characterized by their almost total independence from eow

Vol.3, No.2, 220; Muhammad Tahir Azhary, 1992, Negara Hukum: suatu Studi tentang Prisst Dilihat dari Segi Hukum Islam, Implementasinya pada Periode Negara Madinah dan Mitos the Legal State: A Study of the Principles seen from Islamic Law and its Implemented in the State and Modern), Bulan Bintang: Jakarta, p. 30.

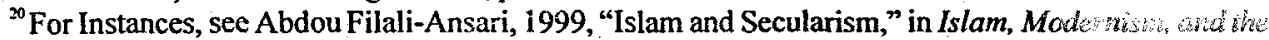
West: Cultural and Political Relations at the End of the Millenium, ed. Gema Martin Munnz, Lurdon: I.B. Tauris, p. 125-35.

${ }^{21}$ Donald Eugene Smith, Religion and Political Developmen:, p. 85.

${ }^{2}$ Nurcholish Madjid, 1998, "The Necessity of Renewing Islamic Thought and Reintigaraing Religious Understanding," in Liberal Islam: A Sourcebook, ed., Charles Kurman, Otimet thiversity Press: New York, p. 286; idem, 1999, Islam Kemodernan dan Keindonesiaan, Mizan: Bandung, 3.207.

${ }_{23} \mathrm{Ibid}$. For study of Nurcholish Majid thought, see Greg Barton, 1995, "Neo-Moderitivit: A Vital Synthesis of Traditionalist and Modemist Islamic Thought in Indonesia," Studia Islamiko, wh 2 No.3, p.

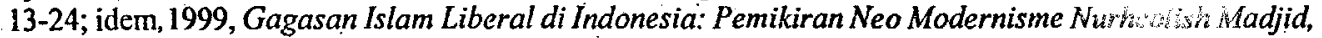
Djohan Effendi, Ahmad Wahib, dan Abdurrahman Wahid, Paramadina: Jakarta, esp. chapter 3 . Translated by Nanang Tahquiq from the author's dissertation at Monash University (1995) within tittle 7.

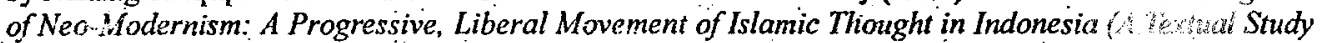
Examining the Writings of Nucholish Madjid, Djohan Effendi, Ahmad Wahid and Abrit? 1968-1980). 
other, while all of them are connected to the West by ties of dependency and. neo-colonial exploitation? ${ }^{24}$

\section{The State in Islam}

In Islam, the state approached by rooted in the concept of daulah as enunciated in the Holy Qur'ân and it was first practised by Prophet Muhammad (p.b.u.h.) through the creation on the state of Madina. ${ }^{25}$ In other place, Abdulaziz Saddiq Jastaniah defined the Islamic state as a state in which authorities, organizations, individuals, and groups accept Islam as their religion and enforce its instructions in all aspects of life. ${ }^{26}$ Hence, Hassan Turabi donated fourth of the Islamic state: Firstly, Islamic states it is not secular. Second, an Islamic state is not a nationalist state because ultimate allegiance is owed to God and thereby to the community of all believers the ummah. Third, an Islamic state is no an absolute or sovereign entity: Finally, an Islamic state is not primordial; the primary institution in Islamic is the ummah. ${ }^{27}$

The term of state itself, enclosed in Islam has many phrases i.e. daulah, kilâfah, hukûmah, imâmah, and sulthan; ${ }^{28}$ nevertheless, the meaning of state in Arabic was al-daulah and their three states: federal state (al-daulah alittihadiyyah), legal state (al-daulah al-qânuniyyah), welfare state (al-daulah arrafâhiyyah). ${ }^{29}$

Again, Serajul Islam states that the state derives power from two sources: Syarî'ah (law) and Ijma' (consensus). ${ }^{30}$ And, on H.A.R. Gibb's words "the Law of Ged, or Syari' $a h$, is the foundation from all discussion of government must start:" ${ }^{31}$ Actually, not only the sources. were play important role in development of Islamic community, ${ }^{32}$ but also, in the same time, to be a crucial debate. For instances, what really the law in. Islam or are different between fiqh and sharî'ah. ${ }^{33}$ Until today, the scholars do not achieve an agreement about this topic.

\footnotetext{
${ }^{24}$ Mohammed 'Abed Al-Jâbiri, "'Clash of Civilizations': The Relations of the Future?," in Islams, Modernism, and the West, p. 73.

${ }^{3}$ Syed Serajul Islam, op.cit., p. 47.

${ }^{36}$ Abdul Aziz Saddiq Jastaniah, 1982, "The Islamic State in Light of the Qur'an and Sunnah," Pd.D. Diss., Claremont Graduate School, p. 1.

${ }^{77}$ Hassan Turabi, 1983, "The Islamic State," in Voices of Resurgent Islam, ed. John L. Esposito, Oxford University Press: New.York, p. 242-3.

${ }^{78}$ For explicit of definition each terms, see generally, Manzoonddin Ahmed, 1988, al-Nazhârijyah alSiyâsah al-Islâmiyyah fi al-'Asr al-Hadîts: An-Nazhâriyyah al-Tatbîq, Jamîah al-Dirã sah al-Islâmiyyah: Pakistan, p. 44-59; Kamaruzzaman, Relasi Islam dan Negara, p. 28-34.

${ }^{2}$ A. Zaki Badawi, 1993, A Dictionary of the Social Sciences, Librairie Du Liban:Beirut, p. 408.

${ }^{30}$ Syed Serajul Islam, op.cit., p. 48.

${ }^{31}$ Hamilton A.R. Gibb, 1970, "The Heritage of Islam in the Modern World (1), "International Josinal Middle East Studies, Vol.I, p. 11.

"See also, Louise Marlow, 1997, Hierarchy and Egalitarianism in Islamic Thought, Cambridge University Press: Cambridge, esp. Part I.
} 
In the same time, in Western culture, also studied syarî'ah and made many interpretation about it.

Briefly, we can examine that in the West many books and articles that Western scholarship concerned the study of Islamic Law. ${ }^{34}$ These indicate that the study of Islamic law has grown up at that place. One of the typical studies of Islamic Law was used in the act of the analysis of social-historical approach. ${ }^{35}$ As result, there are seven topics (or questions) concerning the study of Islamic Law at Western. First, the questions of the origins, secondly, the questions of foreign influences on early Islamic law. Third, the questions of legal changes vs. immutability in Islamic Law. Fourth, the question of law and medieval religious education. Fifth, the question of the conflict between realism and idealism. Sixth, the question of the status of women and children in traditional and modern Islam. Seventh, the question of modern legal reform and the need for new legal theory. ${ }^{36}$ As result, many aspects of Islamic teaching are questioned, and one of the most serious questions is addressed to the doctrine of Islamic law."

It would keep in our mind that why the Muslim countries did not apply the Islamic law as well and still controversial debates about it. As Knut S. Victor stated that the questions should be essential to the theoreticians of the Islamist groups, but it also of interest to the outside observer, because it can illuminate both something of nature of Islamic law, and perhaps also cast some light on the Islamic groups in quetsion. ${ }^{38}$ Finally, we do not front the Islamic State in this world, but only Muslim State. It is not surprising when G.W. Choudhury classifies Muslim nation state in three categories and did not mention the

\footnotetext{
${ }^{33}$ On this, see Kamaruzzaman, 1999, "Kontribusi Daerah Aceh terhadap Perkembangan Awal Hukum Islam di Indonesia (The Contribution of Aceh in the Early Development Islamic Law in Indonesia)," $\mathrm{Al}$ Jâmi'ah, No.64/XII, p. 146-50; Kamaruzzaman, Relasi Islam dan Negara, p. 105-08.

${ }^{34}$ Generally, see R. Stephen Humphreys, 1991, Islamic History: A Framework for Inquiry, Revised Edition, Princeton University Press: Princeton, esp. chapter IX, "Islamic Law and Islamic Society," pp. 209-27; Akh. Minhaji, 1993, "Islamic Law in Western Scholarship: A Bibliographical study with Emphasis on the Work of Joseph Schacht and Its Influence on His Successor," Al-Jâmi'ah, pp. 94-8; idem, "Hukum Islam di Mata Sarjana Barat: Kajian Bibliografi Terhadap Tesis Joseph Schacht dan Beberapa Tanggapar Terhadapnya (Islamic Law in Western Scholarship: A Bibliographical study with Emphasis on the Work of Joseph Schacht and Its Influence on His Successor)," in Sudarnoto Abdul Hakim, Hasan, and Yudian W. Asmin (Eds.), 1995, Islam Berbagai Perspektif: Didekasikan Untuk 70 Tahun Prof. Dr. H. Munowir Sjadzali, MA. LPMI: Yogyakarta, p. 63-79.

${ }^{35}$ - Ratno Lukito, 1996, "Studi Hukum Islam antara IAIN dan McGill (The Study of Islamic Law between IAIN and McGill)," in Yudian W. Asmin (ed), 1996, Pengalaman Belajar Islam di Kanada, Titian Tlahi Press: Yogyakarta, p. 153.

${ }^{30}$ Ibid., 156-61.

${ }^{37}$ Akh. Minhaji, 1992, "Joseph Schacht's Contribution to the Study of Islamic Law," M.A Thesis, McGill, p. 19; idem, 1997, "Orientalisme dalam Bidang Hukum Islam (Orientalism in Islamic Law Studies)," Republikci Online, 13 September, p. 5.a

${ }^{38}$ Knut S. Victor, 1998, "The Shari'a and the Nation State: Who can Codify the divine Law?," a working paper presented in the Fourth Nordic Conference on Middle Eastern Studies: The Middle East in Globalizing World, Oslo, p. 13-16.
} 
Islamic State definitely:

1. There are some Muslim states like Afghanistan, Iran, Pakistan, Saudi Arabia, and Sudan which designate themselves Islamic states.

2. There is, however, the vast majority of Muslim countries which do not claim to be Islamic states; there are references to Islam sometimes in a form such as 'state religion', or in some other way. These countries are governed mainly by Western legal codes but in personal matters such marriage, inheritance etc., Islamic law or syarî'ah is used.

3. There are very few Muslim countries which would prefer to have a 'Secular State' on the pattern of the Western concept of the separation of politics and religion (in the narrow concept of religion as a 'mode of worship' and not in the broader concept of Islam, which regards religion as a code of the entire human life)..$^{39}$

Historically, the Islamic State has practiced in era of Muhammad; but, again, he did not mention that he made the Islamic State or based on Koran itself. ${ }^{40}$ Jastaniah, however, has identified 19 characteristics Muhammad as a Prophet of Islam and leader of the Muslims in their religious and secular affairs: (1) piety and strong faith; (2) unique wisdom and intelligence; (3) great ability to influence his followers and capability to direct and control affairs; (4) real enforcement of justice and equality; (5) deep concern; (6) unique and strong personality that was loved and admired by Muslims and some non-Muslim alike; (7) correct selection of employees and willingness to delegate authority; (8) willingness to practice mutual consultation; (9) knowledge and experience in both religious and secular affairs; (10) ability to carry responsibility; (11) ability to make the right decision at the right time; (12) ability do define goals and objectives and make them clear to all people; (13) good physical ability; (14) knowledge of the principles of warfare; (15) ability to devise strategies; (16) ability to promote a mutual love and trust between him and his followers; (17) bravery and constant devotion to truth; (18) humanity and mercy in warfare as well as in peacetime; and (19) patience and complete trust in Allah."

Besides these, it is also advance to cite Marshall G.S. Hodgson opinions

\footnotetext{
"See G.W. Choudhury, 1994, Islam and the Modern Muslim World, Kuala Lumpur, p. 95-6. See also, J.N.D. Anderson, 1959, Islamic Law in the Modern World, New York University Press: New York, p. 82-3; John L. Esposito, 1997, "Introduction," in John L. Esposito (ed.), Political Islam: Revolution, Radicalism, or Reform, Lynne Rienner Publisher: London, p. 2; Tajul Arifin, 1998, "The Application of Syari'ah Law in Muslim Countries: A Sociological Analysis," Mimbar Studi, No. 1, XXII (September-December, p. 17392.

${ }^{*}$ See generally Mustafä Hilmi, op.cit., p. 13-29.

"Abdulaziz Saddiq Jastaniah, 1964, "The Islamic State in Light of the Qur'an and Sunnah," pp. 116-7. See also M.A. Rauf, 1964, The Life and Teaching of the Propeht Muhammad Longman of Malaysia: Kuala Lumpur; Rafiq M. Khan, 1952, in the Footsteps of the Prophet. Macmillan and CO: London, Limited; Nourouzzaman Shiddiqi, 1996, Jeram-Jeram Peradaban Muslim, Pustaka Pelajar: Yogyakarta, pp. I(10-1.
} 
when he said that:

- Muhammad's society came to include both Muslims and non-Muslim in various degrees of membership. It had long since ceased to benuust a new tribe of the faithful, or even a local voluntary association. It was becoming a complex and extensive society of heterogeneous element, more fully organized than had been the Meccan system (both religiously and politically); the political structure which Muhammad was building for it was by no clearly a state, like the states in the nations round about Arabia, with an increasingly authoritative government, which could no longer be ignored with impunity. Muhammad sent out envoys, who thought the Qur'an and the principles of Islam, collected the zakat, and presumably arbitrated disputes so as to keep the peace and prevent feuding. The Muslim of Medina thus undertook to bring into being throughout much of the Hijaz, and even beyond it, a way of living which should be just and godly. They depended fundamentally, to be sure, on the willingness of a majority to accept the system for the sake of its more immediate benefits in peace among themselves and strength against rivals outside. But the ideal was to be established whether with or without the active co-operation of the various trib.s. ${ }^{42}$

From above description, it is important to note that Muhammad has built the Islamic State and "Islamic nation state", but not nation state in the West. Because, the idea State in Islam is essentially contrasted from the idea of modern nationStates in the West. The two types, according Kalim Siddiqui, are not the same: they have nothing in common. While Islam brings the State into existence as an instrument of Divine purpose, the nation-State comes into existence for precisely the opposite reason: to dismiss God and to replace Him with the 'national interest' as determined by human reason. ${ }^{43}$ Furthermore, Kalim also state that:

This is hardly surprising in a situation where the highest form of political organization, the nation-State, itself does not recognize any moral values, except those of the profane world. Such values neither immutable nor universal. They are different from nation-State to nation-State, and in the same nation-State different values are often used in different situation depending on the 'national interest' involved in each situation. Not surprisingly, therefore, international relations between nation-States represent a struggle for power, by means of power, for the sake of more power. $^{44}$

Indeed, what we want to say is the Islamic nation-states was the state embodies from various tribes that made the consensus to life together and based

\footnotetext{
4 Marshall G.S. Hodgson, 1977 , The Venture of Islam: Conscience and the History in a World Civilization 1 (The Classical Age of Islam), The University of Chicago Press: Chicago, p. 193.

${ }^{43}$ Zafar Bangash (ed.), 1996, In Pursuit of the Power of Islam: Major Writings of Kalim Siddiqui, The Open Press:London, p. 107.
} 
on the principles of religion that accepted by people. ${ }^{45}$ From the era of Muhammad, we can point that how modernized Muhammad at that time could govern the people from the various tribes and interesting and based on the Islamic teaching.

In addition, Muhammad also promulgated the al-Dustûr al-Madînah : (Constitution of Madinah) in which contains 47 articles. ${ }^{46}$ According to scholars, ${ }^{47}$ there were many lessons from this constitution: First, the people of Madinah ware came from many tribes, namely ancestries, cultures, and religion. Tie of unity was the power of political in the same destination (art. 17;23 and 41). All of people whom support the constitution were Mukmin (believer). Second, the followers before were two categories: (a) Muslim (believer) and (b) non-Muslim (non-believer). The links between Muslim were friends one to the other to the exclusion of all men (art. 15;14;19 and 21). Third, the state gives safety the freedom of religion for non-believer (art. 25 until 33). Fourth, the equality between citizenship (art.16). Hence the weakness must be help and

${ }^{4} I$ Ibid., p. 109. For example, according to freedom house, American was the very democratic state in the world. However, in the recently election there was a problem of election in Fiorida It seem was unfairly actions. See generally David Barstow and Don Natra Jr., "How Bush Took Florida: Mining the Overseas Absente Vote;" New York Times, I ily $15-14$ (2001), "http:/www.nvtimes.com/2001/07/15/politics/15BALL.html?todaysheadlines; "Florida's Flawed Ballots," New York Times, July, 16 (2001), hrtp://www.nytimes.com/2001/07/16/opinion/16MON1.html; Katharine Q. Seelye, "Study Says 2000 Election Missed Millions of Votes," New York Times, July, 16 (2001) http://www.nytimes.com/2001/07/17/politics/17VOTE.htmi?todaysheadlines. For study of democracy, see Philippe C. Schimitter, "Perkembangan Mutakhir dalarn Studi Akademis Demokratisasi: Pelajaran bagi Indonesia dari "Transitologi" dan "Konsolidologi (The Recently Academic Study of Democratization: A Lesson for Indonesia form "Transitology" and "Concidology"), Jurnal Demokrasi \& HAM, Vol.1, No.3 (2001), 91-121; R. William Liddle and Saiful Mujani, 2000, "Islam, Kuitur Politik, dan Demokratisasi (Islam, Political Culture, and Democratization), "Jumal Demokrasi \& Ham. Vol. I, No. 1; p. 132-66; Kamaruzzaman, 2000, "Menggagas Demokrasi Agama di Indonesia: Perspektif Sistem Politik Islam (The Concept of Democracy of Religion: Islamic Political System Perspective),"Profetika, Vol. 2, No.1, p. 37-55; For problem of power in global context, for instance, see John C. Raines, 2001, "Peace and Justice in Global Perspective," a Paper presented at International Conference World Peace in Light of Qur'anic Teaching. Sahid Jaya Hotel : Makassar, June 1-3; Robert L. Bartley, 2001, “ Resposes to Samuel P. Huntington's "The Clash of Civilizations? " The Case for Optimism; The West Should Believe in Itself'; Anthony H. Birch, 2001, The Concepts and Theories of Modern Democracy, $2^{\text {nd }}$ edition, London: Routledge, p. 71-92.

${ }^{45}$ See also, Munawir Sjadzali, 1999, "Kembali ke Piagam Madinah: Return to Constitution of Madinah," in Abu Zahra (ed.), 1999, Politik Demi Tuhan: Nasionalisme Religious di Indonesia (In the Name God in Politic: Nationalism Religious in Indonesia; Pustaka Hidayah: Bandung, p. 335.

${ }^{45}$ For English translation, see Abdulaziz Saddiq Jastaniah, "The Islamic State in Light of the Qur'an and Sunnah;" p. 125-29. For Arabic texts, see Ahmad Stikardja, Piagam Madinah dan Undang-Undang Dasar 1945;- pp. 191-4. For Indonesian translations, see Nourouzzaman Shiddiqi, Jeram-Jeram Peradabä Muslim, p. 87-93: Munawir Sjadzali, 1993, Islam dan Tata Negara: Ajaran, Sejarah dan Pemikiran (Islam and Governmental System: Teaching, History and Considerations), UI Press: Jakarta, 1993, p. 10 -15.

${ }^{47}$ Nourouzzaman Shiddiqi, op.cit., pp. 93-4, Munawir Sjadzali, Islam dan Tata Negara, op. cit., pp. 15. 6. See also, Ahmad Baso, 1999, Civil Society Versus Masyarakat Madani: Arkeologi Pemikiran "Civil Society" dalam Islam Indonesia, Pustaka Hidayah: Bandung, pp. 331-52; Akh. Minhaji, "Wawasan Islam tentang Negara dan Pemerintahan (Perspektif Normatif-Empiris): Sebuah Pengantar," in Kamaruzzaman. Relasi Islam dan Negara, fn.34, liii. 
Drotect (art.11). Although there many another explanations, but it would say the lamic State in era of Muhammad was very modernize. Moreover, the problem n contemporary era is how the Muslim could apply the blue print Islamic State shat have Muhammad did. In short, there is not data show that in Islam the religion separates from state.

\section{Concluding Remark}

The above discussion clearly shows that there is not data support to say that religion and state must be separate. The fact of separation between religion and state only in the West, because the Christian's Holy Book does not te ch about religion. So, in the West emerge the secularisation. Comparison with state in Islam, there many data show both normative and historic, show how the combined the religion and state.

\section{BIBLIOGRAPHY}

Ajami, Fouad, "Responses to Samuel P. Huntington's "The Clash of Civilizations? JEREMIAH 6:17Syed Serajul Islam, “ The Western and Islamic Approaches to the State," 45

Anderson, J.N.D., 1959, Islamic Law in the Modern World, New York: New York University Press.

Ansari, Abdou Filali, 1999, "Islam and Secularism," in Islam, Modernism, and the West: Cultural and Political Relations at the End of the Millenium, ed., London: Gema Martin Munoz, I.B. Tauris.

Arifin, Tajul, 1998, "The Application of Syari'ah Law in Muslim Countries: A Sociological Analysis," Mimbar Studi, No.1, XXII

Asmin, Yudian W. (ed), 1996, Pengalaman Belajar Islam di Kanada, Yogyakarta: Titian Ilahi Press.

Azhary, Muhammad Tahir, 1992, Negara Hukum: suatu Studi tentang PrinsipPrinsip Dilihat dari Segi Hukim Islam, Implementasinya pada Periode Negara Madinah dan Masa Kini (The Legal State: A Study of the Principles seen from Islamic Law and its Implemented in the era of Madinah State and Modern), Jakarta: Bulan Bintang.

Ahmed, Manzooruddin, 1988, al-Nazhâriyyah al-Siyâsah al-Islâmiyyah fí al'Asr al-Hadîts: An-Nazhâriyyah al-Tatbîq, Pakistan: Jamî'ah al-Dirâsalk al-Islâmiyyah. 
Badawi, A. Zaki, 1993, A Dictionary of the Social Sciences, Beirut:Librairie Du Liban.

Barton, Greg, 1995, "Neo-Modernism: A Vital Synthesis of Traditionalist and Modernist Islamic Thought in Indonesia," Studia Islamika, Vol.2, No.3.

----, 1999, Gagasan Islam Liberal di Indonesia: Pemikiran Neo Modernisme Nurhcolish Madjid, Djohan Effendi, Ahmad Wahib, dan Abdurrahman Wahid, Jakarta: Paramadina.

Bangash, Zafar (ed.), 1996, In Pursuit of the Power of Islam: Major Writings of Kalim Siddiqui, London: The Open Press.

Baso, Ahmad, 1999, Civil Society Versus Masyarakat Madani: Arkeologi Pemikiran "Civil Society" dalam Islam Indonesia, Bandung: Pustaka Hidayah.

Bartley, Robert L., 2001, "Resposes to Samuel P. Huntington's "The Clash of Civilizations?". The Case for Optimism; The West Should Believe in Itself"; Anthony H. Birch, 2001, The Concepts and Theories of Modern Democracy, $2^{\text {nd }}$ edition, London: Routledge.

Budiarjo, Miriam, 1999, Dasar-Dasar Ilmu Politik: the Principles of Political Science, Jakarta: Gramedia Pustaka Utama,

Chilcote, Ronald, 1981, Theories of Comparative Politics: the Search for Paradigm, Westview Press: Boulder, p. 139-201.

Choudhury, G.W., 1994, Islam and the Modern Muslim World, Kuala Lumpur.

Evera, Stephen Van, 1977, Guide to Methods for Students of Political Science, Ithaca and London: Cornell University Press.

Esposito, John L., 1997, "Introduction," in John L. Esposito (ed.), Political Islam: Revolution, Radicalism, or Reform, London: Lynne Rienner Publisher.

Faksh, Mahmud A., 1983, "Theories of State in Islamic Political Thought," Journal of South Asian and Middle Eastern Studies, Vol. VI, No.3,

Gibb, Hamilton A.R., 1970, "The Heritage of Islam in the Modern World(1)," International J̦ournal Middle East Studies, Vol.I.

Hakim, Sudarnoto Abdul, Hasan, and Yudian W. Asmin (Eds.), 1995, Islam Berbagai Perspektif $\therefore$ Didekasikan Untuk 70 Tahun. Prof. Dr. $H$. Munawir Sjadzali, MA. Yogyakarta: LPMI.

Hamlyn, D.W., 1971, "Epistemology," in The Encyclopedia of Philosiphy, ed. Paul Erwasds, London: Collier Macmillan Publisher. 
Hilmi, Mustafâ, 1998, Nidâm al-Kilafâh Bain Ahl al-Sunnah wa al-Syt̂'ah: Muktasâr Nidâm al-Kilafâh fí al-Fikr al-Islâmiyy, Iskandariyyah: Dâr al-Da'wah

Huntington, Samuel P., 1998, The Clash of Civilizations and the Remaking of World Order, London: Touchstone Books.

Humphreys, R. Stephen, 1991, Islamic History: A Framework for Inquiry, Revised Edition, Princeton: Princeton University Press.

http://www.nytimes.com/2001/07/15/politics/15BALL.html?todaysheadlines http://www.nytimes.com/2001/07/16/opinion/16MON1.html

http://www.nytimes.com/2001/07/17/politics/17VOTE.html?todaysheadlines.

Islam, Syed Serajul, 1997, "The Western and Islamic Approaches to the State: A Comparative Analysis," Muslim Education Quarterly, Vol.14, No.4.

Jacobsohn, John A., 1998, An Introduction to Political Science, Albany: West Wasdsworth.

Jastaniah, Abdul Aziz Saddiq, 1982, "The Islamic State in Light of the Qur'an and Sunnah," Pd.D. Diss., Claremont Graduate School.

Kamaruzzaman, 2000, "Menggagas Demokrasi Agama di Indonesia: Perspektif Sistem Politik Islam (The Concept of Democracy of Religion: Islamic Political System Perspective),"Profetika, Vol.2, No.1.

-.---, 2001, Relasi Islam dan Negara: PerspektifModernis \& Fundamentalism, Magelang: IndonesiaTera.

-----, "Reorientasi Pemikiran Kenegaraan dalam Islam," Profetika, Vol.3, No.2

-----, 1999, "Kontribusi Daerah Aceh terhadap Perkembangan Awal Hukum Islam di Indonesia (The Contribution of Aceh in the Early Development Islamic Law in Indonesia)," Al-Jâmirah, No.64/XII.

Khadduri, Majid, 1951, "The Juridical Theory of the Islamic State," Muslim World, Vol.41, No.3

Lapidus, Ira M., 1975, "The Separation of State and Religion in The Development of Early Islamic Society," International Journal Middle East Studies.

Little, Donald P., 1974, “A New Look At Al-Ahkâm al-Sultâniyya," The Muslim World, Vol:LXIV;No. 1

Liddle, R. William and Saiful Mujani, 2000, "Islam, Kultur Politik, dan Demokratisasi (Islam, Political Culture, and Democratization), " Jurnal Demokrasi \& Ham, Vol.1 
Madjid, Nurcholish, 1998, "The Necessity of Renewing Islamic Thought and Reinvigorating Religious Understanding," in Liberal Islam: A Sourcebook, ed., Charles Kurman, Oxford University Press: New York.

.----, 1999, Islam Kemodernan dan Keindonesiaan, Mizan: Bandung.

-.---, 1998, "Islam dan Politik: Suatu Tinjauan atas Prinsip-prinsip Hukum dan Keadilan (Islam and Politic: A General Outlook from The Principles of Law and Justice)," Paramadina, Vol. I, No.1.

Mawardi, al-, al-Ahkâm al-Sultâniyyah (the Principles of Government), Beirut: Dâr al-Fikr,

Marlow, Louise, 1997, Hierarchy and Egalitarianism in Islamic Thought, Cambridge University Press: Cambridge.

Mulyati, Sri, 1997, "The Theory of State of Al-Mâwardî," in Sri Mulyati (et al), Islam \& Development: A Politico-Religious Response, Yogyakarta: Lembaga Penterjemah \& Penulis Muslim Indonesia and Permika Montreal.

Minhaji, Akh., 1993, "Islamic Law in Western Scholarship: A Bibliographical study with Emphasis on the Work of Joseph Schacht and Its Influence on His Successor," Al-Jâmi'ah

-_--, 1992, "Joseph Schacht's Contribution to the Study of Islamic Law," M.A Thesis, McGill

-----, 1997, “Orientalisme dalam Bidang Hukum Islam (Orientalism in Islamic Law Studies)," Republika Online, 13 September.

Noer, Deliar, 1999, Pemikiran Politik di Negeri Barat, Bandung: Mizan.

Polkinghorne, Donald, 1983, Methodology for the Human Sciences: System of Inquiry, Albany: State University of New York Press.

Raines, John C., 2001, "Peace and Justice in Global Perspective," a Paper presented at International Conference World Peace in Light of Qur'anic Teaching, Sahid Jaya Hotel Makassar, June

Rauf, M.A., 1964, The Life and Teaching of the Propeht Muhammad, Kuala Lumpur: Longman of Malaysia.

Sjadzali, Munawir, 1999, "Kembali ke Piagam Madinah: Return to Constitution of Madinah," in Abu Zahra (ed.), 1999, Politik Demi Tuhan: Nasionalisme Religious di Indonesia (In the Name God in Politic: Nationalism Religious in Indonesia, Bandung: Pustaka Hidayah.

Shiddiqi, Nourouzzaman, 1996, Jeram-Jeram Peradaban Muslim, Yogyakarta: Pustaka Pelajar. 
Smith, Donald Eugene, 1970, Religion and Political Development, Boston: Little Brown.

Sukardja, Ahmad, 1995, Piagam Madinah dan Undang-Undang Dasar 1945, Jakarta: UI Press.

Taymiyya, Ibn, 1998, al-Khilâfah wa al-Mülk, Yordan: Maktabah al-Manâr.

Ya'lâ, Abî, 1994, Al-Ahkâm al-Sultâniyyah (the Principles of Government), Beirut: Dâral-Fikr.

Turabi, Hassan, 1983, "The Islamic State," in Voices of Resurgent Islam, ed. John L. Esposito, New York: Oxford University Press.

Victor, Knut S., 1998, "The Shari'a and the Nation State: Who can Codify the devine Law?," a working paper presented in the Fourth Nordic Conference on Middle Eastern Studies: The Middle East in Globalizing World, Oslo.

Wartofsky, Marx W., 1971, "Epistemology," in The Encyclopedia of Education, ed. Lee C. Daighton, USA: L The Macmillan Company \& The Free Press.

Zaman, Muhammad Qasim, 1997, "The Caliph, The 'Ulamâ', and the Law: Defining the Role and Function of the Caliph in The Early 'Abbasid Period," Islamic Law and Society, Vol.4, No.1, 1-36. 